\title{
Malignant Vascular Neoplasm
}

National Cancer Institute

\section{Source}

National Cancer Institute. Malignant Vascular Neoplasm. NCI Thesaurus. Code C7390.

A malignant neoplasm arising from the vascular tissue. It is characterized by vascular channel formation and malignant endothelial cells. 